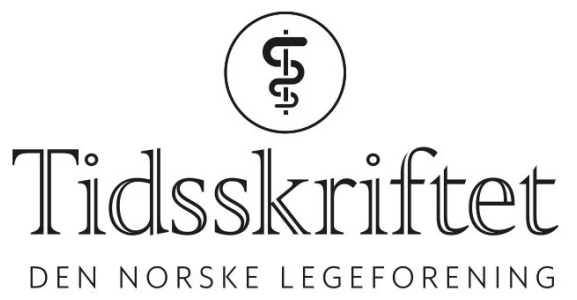

\title{
Arnold Berstad
}

MINNEORD

JØRGEN VALEUR

TRYGVE HAUSKEN

JAN GUNNAR HATLEBAKK

GÜLEN ARSLAN LIED

GEIR FOLVIK

KRISTINE LILLESTØL

GUNNAR NYSAETER

TORE MIDTVEDT

INGVARD WILHELMSEN

LARS BIRGER NESJE

ODD HELGE GILJA 


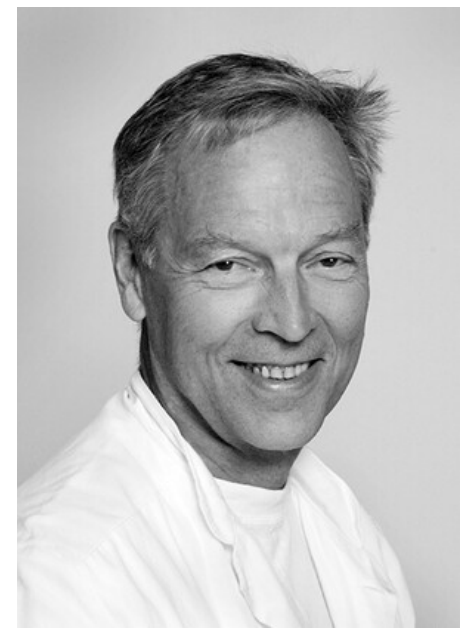

Arnold Berstad døde nyttårsaften 2020. Norge har mistet en av sine fremste gastroenterologer - kanskje den mest nysgjerrige, nytenkende og inspirerende.

Arnold ble født i Stryn i 1940 og vokste opp på gård som eldst av sju søsken. Han ble cand.med. ved Universitetet i Oslo i 1965, og startet sin akademiske karriere på IX. avdeling ved Ullevål sykehus i 1968. I 1971 disputerte han på et arbeid om fordøyelsesenzymet pepsin - et av de mest siterte arbeidene innen gastroenterologi på den tiden.

I 1972 begynte Arnold sin kliniske utdannelse på Lovisenberg Diakonale Sykehus, der han etter hvert ble overlege og spesialist i indremedisin og i fordøyelsessykdommer, og etablerte et aktivt forskningsmiljø hvorfra det utgikk i alt seks doktorgrader.

I 1987 var han gjesteforsker ved University of Alabama at Birmingham i USA, ledet av nobelprisnominerte professor Basil I. Hirschowitz (1925-2013). Vennskapet og den faglige sparringen med Hirschowitz ble livslang. Samme år ble han «kalt til tjeneste» som leder for gastroseksjonen ved Medisinsk avdeling ved Haukeland universitetssjukehus, og professor ved Universitet i Bergen. De neste årene utgikk avhandlinger om funksjonell dyspepsi, Helicobacter pylori, reflukssykdom og matoverfølsomhet på løpende bånd. Arnolds evne til å stimulere vitenskapelig nysgjerrighet og til å inkludere nye personer gjorde at Bergen ble et internasjonalt tyngdepunkt innen gastrointestinal forskning. Han bidro til opprettelsen av nasjonale kompetansesentre i gastroenterologisk ultrasonografi og funksjonelle magetarmsykdommer, og var sentral ved etableringen av ernæringsstudiet ved Universitetet i Bergen.

Da Arnold i 2010 ble professor emeritus, vendte han tilbake til Lovisenberg, der han var med på å utvikle forskningsenheten Unger-Vetlesens Institutt. Han var svært populær blant pasientene, som han fulgte opp langt utover det vanlige.

Arnold har over 400 registrerte publikasjoner i PubMed. Han har veiledet 35 doktorgradskandidater - uoffisiell norsk rekord blant kliniske forskere. Hans anseelse internasjonalt gjorde at det å tilhøre «Arnold's group» ble en døråpner for yngre kolleger inn i de beste forskningsmiljøer i alle verdensdeler. I 2002 fikk Arnold Scandinavian Journal of Gastroenterology sin ærespris, etterfulgt av en periode som redaktør. I 2002 mottok han Dr. Falchs pris for fremragende forskningsledelse. Han var medlem av European Gastro Club, Erlangen og American Gastroenterology Association og æresmedlem i Norsk Gastroenterologisk Forening.

Som forsker var Arnold kjennetegnet av originalitet, idérikdom og kreativitet. Hans engasjement for faget var nærmest altomfattende, og entusiasmen smittsom. Det var ingen dørterskel inn til hans kontor. Han fant alltid det positive i situasjonen og sa aldri et vondt ord om noen. Slike egenskaper gjorde ham til en inspirator og en høyt verdsatt veileder. Vi spurte en gang Arnold om hva som var drivkraften hans. «Jeg lever og ånder hver dag i forestillingen om at et stort gjennombrudd er like om hjørnet», var svaret. 
Arnold hadde en sterk tro på det han drev med, og hans mot og vitenskapelige dristighet bar frukt i rikt monn. Flere av hans stipendiater er i dag kliniske forskningsledere og forsøker å arbeide videre etter Arnolds idealer. Våre varmeste tanker går til hans kone Tove, sønnene Ketil, Audun og Terje, og alle andre i den store familien.

Publisert: 22. februar 2021. Tidsskr Nor Legeforen. DOI: 10.4045/tidsskr.21.0oo9

(C) Tidsskrift for Den norske legeforening 2023. Lastet ned fra tidsskriftet.no 26. april 2023. 